by intraspinal injection. Arch Neurol 1988;45:804-6.

24 Charcot J, Joffroy A. Deux cas d'atrophic musculaire progressive avec lesions de la substance grise et des fasiceaux anterolateraux de la moeille 'epinie're. Arch Physiol 1869;2:354-63.

25 Schwarz E. Praparate von einem falle syphilitischer myelomeningitis mit holenbildung im Ruchenmarke und besonderen degenerativen Veranderungen der Neurologlia. Wien Klin Wchschr 1897;10:177

26 Alajouanine T, Hornet T, Thurel R, Andre R. Le feutrage arachnoidien posterieur dans la syringomelie. Rev Neurologique 1935;64:91-8.

27 Mackay R. Chronic adhesive spinal arachnoiditis. JAMA 1939;112:802-8.

28 Newman P, Terenty T, Foster J. Some observations on the pathogenesis of syringomyelia. J Neurol Neurosurg Psychiatry 1981;44:964-9.

29 Hankinson J. Syringomyelia and the surgeon. In: Williams D, ed. Modern Trends in Neurology. London: ButterD, ed. Modern Trends
worths, 1970:127-48.

30 Appleby A, Bradley W, Foster J, Hankinson V, Hudgson P. Syringomyelia due to chronic arachnoiditis at the foramen
Sy Syringomyelia due to chronic arachnoidit

31 De la Monte S, Horowitz S, Larocque A, Richardson EP.
Keyhole aquaduct syndrome. Arch Neurol 1986;43:926-9. 32 McLaurin R, Bailey O, Schurr O, Ingraham F. Myelomalacia and multiple cavitation of spinal cord secondary to malacia and multiple cavitation of spinal cord secondary to Pathol 1954;57:138-46.

33 Williams B. On the pathogenesis of syringomyelia: A review. $J$ Roy Soc Med 1980;73:798-806.

34 Gardner WJ. The dysraphic states. Amsterdam: Excerpta Medica, 1973.

35 Barbaro N, Wilson C, Gutin P, Edwards M. Surgical treatment of syringomyelia: favorable results with syringoperitoneal shunting. $J$ Neurosurg 1984;61:531-8.

36 Blaylock R. Hydrosyringomyelia of the conus medullaris associated with a thoracic meningioma. J Neurosurg 1981; 54:833-5.

37 Harbitz F, Lossius E. Extra-medullary tumor: Arachnoiditis fibrosa cystica et ossificans; Gliosis of the medulla. Acto Psychiatr et Neurol 1929;4:51-64.

38 Tauber E, Langworthy O. A Study of Syringomyelia and formation of cavities in the Spinal Cord. J Nerv Ment Dis 1935;81:245-64.

39 Simmons JD, Norman D, Newton TH. Pre-operative demonstration of post-inflammatory syringomyelia. AJNR 1983;4:625-8.

\section{Robert Graves and multiple neuritis}

Many studies of paralysis of the limbs had been conducted in the 18th and 19th centuries, but the concept that this might result from diseases remote from the brain, cord and spinal roots was not recognised. Wasting was due to disorders of the muscles and sensory loss related to defects of the skin. It was recognised that these symptoms occurred in "alcoholic paraplegia" and probably in lead and arsenic poisoning where they were caused by the diarrhoea or constipation. Samuel Wilks had thought the cause might be due to a reflex paralysis "the cord is in no way structurally altered, and therefore may ... recover ..."

Polyneuropathy is a recent name replacing Ernst von Leyden's (1832-1910) term" "multiple neuritis". The first account was probably one of beriberi neuritis described by Bontius in $1642 .{ }^{3}$ Robert Graves (17961853 ) in 1843 deserves credit for first predicating disease of the peripheral nerves as a cause of paralysis. Graves, remembered for his description of exophthalmic goitre (after Caleb Parry), was a Dublin graduate who had travelled with the artist Turner in Europe. In Paris in 1828 he observed the remarkable and obscure, epidemic of acute sensori-motor polyneuropathy. Described by Auguste-Francois Chomel ${ }^{4}$ it was known as epidemie de Paris. Graves's account in 1843 is to be found in his Clinical Lectures 5 .

"One of the most remarkable examples of disease of the nervous system commencing in the extremities, and having no connection with lesions of the brain or spinal marrow, was the curious epidemie de Paris, which occurred in the spring of 1828 . Chomel has described this epidemic in the 9 th number of the Journal Hebdomadaire, and having witnessed it myself in the months of July and August of the same year, I can bear testimony to the ability and accuracy of his description. It began (frequently in persons of good constitution) with sensations of pricking and severe pain in the integuments of the hands and feet, accompanied by so acute a degree of sensibility, that the patients could not bear these parts to be touched by the bed-clothes. After some time, a few days, or even a few hours, a diminution, or even abolition of sensation took place in the affected members, they became incapable of distinguishing the shape, texture, or temperature of bodies, the power of motion declined, and finally they were observed to become altogether paralytic. The injury was not confined to the hands and feet alone, but, advancing with progressive pace, extended over the whole of both extremities. Persons lay in bed powerless and helpless, and continued in this state for weeks and even months ...

At last, at some period of the disease, motion and sensation gradually returned, and a recovery generally took place, although, in some instances, the paralysis was very capricious, vanishing and again reappearing.

The French pathologists, you may be sure, searched anxiously in the nervous centres for the cause of this strange disorder, and could find none; there was no evident lesion, functional or organic, discoverable in the brain, cerebellum or spinal marrow . . . Can anyone ... hesitate to believe that paralysis ... may arise from disease commencing and originating in the nervous extremities alone?"

Gowers gave him less than credit due, but Trousseau remarked that "Graves had created a class of peripheral or reflex paralyses . . ." Octave Landry's celebrated report of ascending paralysis ${ }^{6}$ in a 43 year old paver followed in 1859 but, curiously, the peripheral nerves were not examined.

It was left to Louis Duménil (1823-90) to demonstrate in a 71 year old stone cutter afflicted by a Landry's paralysis the pathological evidence of "a genuine atrophy of the medullary substance of the peripheral nerve tubes" and related loss of transverse striations of shrunken muscle fibres in the periphery.

JMS PEARCE

1 Wilks S. Lectures on diseases of the nervous system delivered at Guy's Hospital. London: Churchill, 1878.

2 Leyden, E von. Ueber poliomyelitis und neuritis. $Z$ klin Med 1879-80;1:387-8.

3 Bontius J. De medicina indorum (1642). English translation 1769, chapter 1, libra IV. cited In: Ralph H Major, ed. Classic descriptions of disease, 3rd edn. Oxford: Blackwell, $1945 ; 605$

4 Chomel A-F. De l'épidémie actuellement régnante à Paris. J Hebomadaire de Médecin 1828;1:333.

5 Graves RJ. Clinical lectures on the practice of medicine. 2nd edn. London: New Sydenham Soc, 1884;574:579-80.

6 Landry O. Note sur la paralysie ascendante aigue. Gazette Hebdomadaire de Médecin 1859;6:472-86.

7 Duménil L. Paralysie périphérique du mouvement et du sentiment portant sur les quatre membres. Atrophie des
sentil rameaux nerveux des parties paralyséés. Gazette Hebdomadaire de Médecin. 1864;1:203. 